\title{
$R_{i}$
}

Journal of Public Value and Administration Insights (JPVAI)

ISSN: 2663-9181

www.readersinsight.net/jpvai

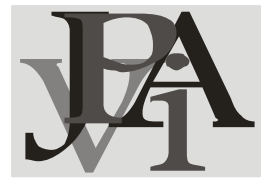

\section{Traditional Institutions and Their Roles: Toward Achieving Stable Democracy in Nigeria}

\author{
Mustapha Alhaji Ali ${ }^{*}$, Hadiza Mali Bukar ${ }^{2}$, \\ ${ }^{1,2}$ Department of Political Science and Administration. Yobe State University, Damaturu, Nigeria \\ *Corresponding author: mustaphaalhajiali2@gmail.com
}

\begin{abstract}
Traditional institutions are formed to play a vital role in society, this paper examined the roles of traditional rulers in accomplishing stable democracy in Nigerian. Indeed, in the olden days, traditional rulers are believing to be royal fathers in their various domain, and they perform better in accomplishing firm democracy, but with coming of colonialist and democracy, the role of the traditional rulers became less recognized in the democratic system. This paper is qualitative in nature where data were obtained from secondary sources, and systematically reviewed these includes; books, journals, newspapers, magazines, published and unpublished documents. The study found that traditional institutions play a significant role in the olden days. But with the advent of the British colonial master and democracy, their power became less recognized in the democratic movements, this is because the traditional rulers were negated and have less power in the society. In explaining the topic under study, the researcher adopted two theories; these are Servant Leadership theory and Dependency theory, these theories centered on the autonomy of the traditional rulers and the qualities of the rulers in each society. the paper recommended that in order to have a steady democracy traditional institution need to be independent in discharging their duties, they also need to serve their people first not people to serve them. The paper concludes that traditional institutions play an important role in achieving a stable democracy if given autonomy and possess all leadership qualities.
\end{abstract}

Keywords: Traditional; Institutions; Roles; Democracy; Nigeria

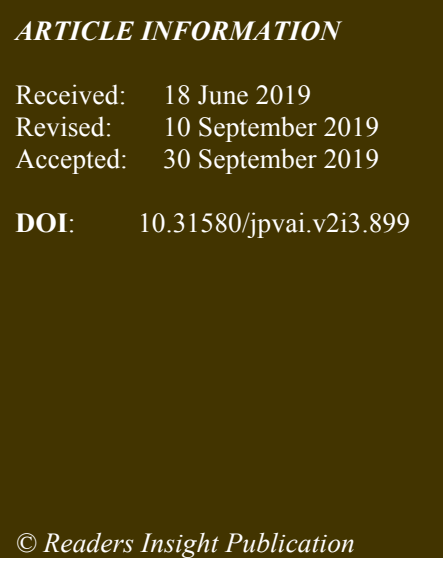

\section{INTRODUCTION}

Nigeria as the most populous Nation in Africa, with perhaps a fifth of the landmass whole population, Nigeria is inevitably a focus of attention its rich and volatile mix of culture, abundant human and natural resources, wealth, and power democratic desire have also made it a focus of political analysis about politics in Africa. However, since its independence in 1960, Nigeria has been widely considered as having one of the best prospects for democratic government in Africa (Diamond, 1988).

Nigeria first became a republic in 1963 but succumbed to military rule three years later after a bloody coup d'état. A nationalist movement later formed the Republic of Biafra in 1967, leading to the three-year Nigerian Civil War. Nigeria became a republic once again after a new constitution was written in 1979. However, the republic was short-lived, when the military seized power again four years later. A new republic was planned to be established in 1993 but was dissolved by General Sani Abacha administration. Abacha Later died in 1998 and a fourth republic was later recognized in a subsequent year, which ended three years of sporadic military rule (Paden, 1986). Nigeria is believing to be one of the largest nations in Africa blessed with human and material resources. The current population of the country in totality is $196,651,048$ (UNDESA, 2018). Nigeria is heterogeneous in nature, this means it comprises people of different background culture, religion, and ethnic groups (Ali, Zakuan, \& Ahmad, 2018; UNDESA, 2018).

Nigeria is honestly an attractive nation with 36 States and a Federal Capital Territory. It has more than 300 ethnic groups and over 500 Spoken Languages, the official Language in Nigeria is English. It is described as "Giant of Africa" Nigeria borders with the Republic of
Benin, Cameroon, Chad, and the Niger Republic. Because of its huge population, diverse culture and economic attainments, the real record of the ethnic groups in Nigeria is not a guarantee. The major, most populated and administratively influenced ethnic group in Nigeria: Hausa, Yoruba, Igbo, Ijaw, Kanuri, and Ibibio, among these ethnic groups, there are minor groups with diverse languages, culture, and lifestyle. Large population and diverse culture, notwithstanding Nigeria, stand unified (Findlay, 2018; Silas, 2018).

Similarly, Sowunmi (2017), disclosed that Nigeria is made of many ethnic groups, the majority of which are Hausa from the north, Yoruba from the west and Igbo from the south. Among these ethnic groups are numerous tribes totaling 371 tribes in the country is provides for well understanding of the beautiful and united nation called Nigeria. All the aforementioned ethnic groups have their culture and traditional system of administrations, the system of administration differ from community to community and society to society (Osifo, 2017; Isaac, 2018).

In line with the above expressions, there are continues questions as to whether traditional authority and democratic governance are ultimately compatible or contradictory (Logan, 2009). The long-time debate on the appropriate role of Africa's traditional rulers in modern politics has strengthened in the last two periods, in an effort to standin democratization and devolution that has brought contending rights to authority and authenticity to the forefront, specifically at the local level (Logan, 2009).

However, in the olden days, traditional institutions are the administrative organizations in Nigerian. These institutions are rooted in the history, cultures, and the traditions of several ethnic groups and cultural background (Isaac, 2018). Traditional institutions played a significant role in the administrative process before, during, and after 
colonial governments, these institutions have contributed to the history of the nation. The role of traditional organizations was important and highly respected during these periods.

During the colonial rule traditional institution were connected to discharged numerous activities, these include but not limited to the administrative process of the colonial masters of indirect rule, promoting the colonial economy through taxes collection. In relation to the political matters, the annexation of the northern and southern protectorates and the demand of the National British of West African State for democratic government placed the traditional organization at the center stage of politics.

In a similar development a study by Nweke (2012), noted that before the advent of the British government in Nigeria, traditional institutions of governance played very important roles in conflict management and firmness as they exercised robust political impacts in their various provinces. Later it opposes that the arrival of colonial masters and post-colonial state in Nigeria, because they politicized the traditional establishments of power, hereafter declining them in living up to their traditional duties of decision making, peace-building, and conflict management.

Immediately after the unification of the two protectorates (Northern and Southern). The traditional institutions were no longer recognized in the society, this is because the Nigeria traditional leaders were seeing as informal members. Emirs from the north and the Alaafin of Oyo supported by official members from Lagos, Calabar, Benin-Warri area. The official introduction of elective rules under the governor general Hugh Clifford in 1922 downgraded the status of the traditional rulers to local administration buttressed through numerous native authority rules declarations, while matters related to politics were left for the elite (Isaac, 2018). This has reduced the power of the traditional institution to native and local authorities at the grass root levels.

In a related development study by Osifo (2017), disclosed that traditional institutions play tremendous roles in achieving stable democracy in every society Nigeria inclusive. It is noted that the role of the traditional institutions in accomplishing stable democracy is very crucial for the peace and development of the nation because traditional institutions hold sway in all the societies and assist the government to provide actual dividends of democracy to the general populous. He further observed that democracy can only succeed when you cultivate and endure its basis, which is the development of social services and economic welfare of the citizenry.

In addition, Osifo (2017), revealed that the role of traditional institutions in accomplishing steady democracy in Nigeria is advisory and not political or managerial. He showcased that before traditional rulers were heads of the government of the respective domain. They were the "law and Jury" and ruled with maximum force. Besides, and in line with a stable democracy, it is understood that politicians respect the royal fathers because they were the guardian of the custom of the people and go to them when they need fatherly advice. With this, traditional institution kept their positions at the mercy of the governors who could employ and overthrow a ruler or chief in the state.

Although, the traditional institution has lost the right to sign an agreement to the title of the land. The constitution gives the power to sign documents of occupancy for rightness to own land. For instance, during the military administration, the government had set aside $5 \%$ for the upkeep of traditional rulers from the revenue allocated to local councils which is the third tier of government, and 1999 constitution did not stop it. Politicians regulate the traditional institutions in understated means. It is known that "he who pays the piper dictates the tune."

\section{Literature Review}

Before, and during colonial administrations, traditional institutions played a significant role in their various communities in uniting and protecting the right and interest of their people, which by extension led to stable democracy and good governance in the nation.
In the olden days, traditional institutions are the administrative organizations in Nigerian, they perform wonderfully in sustaining peace and development in the nation that helps in achieving stable democracy in the nation (Nweke, 2012; Isaac, 2018).

The central argument is that Nigerian traditional institutions have, in several respects, were negated from the political structure followed the similar path from colonial manipulation to postcolonial maladministration. Which has changed over the years has been the beneficiaries of Africa's exploitation. Political liberation has so far not shaped stable institutions and stable development in most African states Nigeria (inclusive) (Kalu \& Falola, 2018).

The dominant argument is that before traditional rulers were the headship of the government of their areas. They were the "lawmaking bodies" and governed with supreme power. It is noted that politicians respect the traditional rulers because they were the protector of the tradition of the people and seek their advice when the need arises. Based on this, royal fathers kept their positions at the compassion of the authorities who could employ and upheaval a ruler or chief in the community or society (Osifo, 2017). Despite their role in sustaining stable democracy in the country in the olden years. Traditional institutions are being neglected to local communities only, their administrative powers were taken by the politicians. This has created a wide vacuum in the democratic set up that need to be filled by incorporating the traditional institutions in policy and decision making of the nation, this would help in sustaining stable democracy. Given this, the paper examined the roles of traditional institutions in accomplishing stable democracy in Nigeria.

\section{OBJECTIVES OF THE STUDY}

1. The paper examined the roles of traditional institutions in achieving stable democracy in Nigeria

2. To explore the effectiveness of the traditional institutions in sustaining stable democracy in Nigeria

\section{Methodology}

This paper is qualitative in nature because it is based on a systematic review of interrelated literature and a sensitive investigation of secondary data, here, data were developed from government and non-governmental sources as well as books, journals, reports and newspaper articles (Braun \& Clarke, 2013; Creswell, 2009).

\section{RESEARCH DESIGN}

This study is Case study approach because it provides the researcher with an in-depth thoughtful of a phenomenon under investigation, or it helps in providing an in-depth understanding of a cases, case study approach is significant in learning an event, a program, an activity through various bases(Creswell, 2013; Othman, 2018).

\section{Theoretical Framework}

In explaining topic under examination, the researcher adopted two theories, these are dependency and servant leadership theory, and justification for using these theories is based on their relevancy and connectivity, they all centered on qualities of leadership and leadership autonomy in the society. The theories are of the opinions that traditional rulers should be an independent body, honest, truthfulness, loyal, accountable, forecast, and prudent in all his administrative affairs. 


\section{SERVANT LEADERSHIP THEORY}

Leadership theory centered on the followers and the leader themselves, essentially, this theory stressed that the leaders are supposed to serve the people first not lead first. Robert K. Greenleaf has been ascribed for introducing this idea of servant leadership in contemporary establishments. However, this theory highlights the type of leaders that rise above selfishness to help peoples. This dwelled on the leadership qualities such as honesty, truthfulness, respectfulness, humility, kindness, commitment, and patience, (Stone; Russell \& Patterson, 2004; as cited in Wooi \& Ismail, 2017; Sami et al., 2016). Moreover, there are some scholars that have vowed for this theory as an effective theory (Washington, 2007).

The evolution of this theory of leadership arose over a century, this was revealed by Stone, A. G., \& Patterson (2005), which is in line with Kuhn's notion, theorizes that "when the existing theory fails to explain a phenomenon, a new theory emerges". Similarly, Yammarino (2013), as cited in Wooi \& Ismail (2017), are of the same view that "when an existing theory is not able to sufficiently account for a phenomenon, the newer theories will eventually replace the older theories".

\section{DEPENDENCY THEORY}

In explaining the role of the traditional institution in accomplishing steady democracy the researcher adopted the dependency theory to support the argument. However, the significance of theory in research cannot be over-emphasized. A study by Nachmias, \& Nachmias (1981), explained that a "theory is a rational and inferential statement consisting of a set of unified ideas from which testable proposal can be derived." Similarly, White and Clark (1990), noted that a theory is "a set of planned explanations logically or systematically related to each other that seek to explain or forecast phenomenon".

Given this, this paper adopted both the Dependency Theory and Servant Leadership Theory as a joint theoretical framework. Dependency Theory in the context of this paper explained the problem of traditional rulers in performing their expected responsibilities toward stable democracy in Nigeria (Nweke, 2012). This theory, thus, is of the view that Nigeria's political instability is a result of negating the roles of traditional institutions and the failure of the political systems that gave much power to elected political leaders at the expense of the traditional institutions, Dependency Theory is exposed to the works of Lenin and Luxemburg in the 1910's and 1920's (as cited in Nweke, 2012; Onah, \& Nyewusira, 2006).

There is a solid argument on these theorists that African nations are constantly controlled politically and economically by the external forces. This assertion is related to the Nigerian context where the country is administrative, politically, and economically managed by the elites and the politicians where the roles of traditional rulers became less relevant in society.

\section{CONCEPTUAL CLARIFICATIONS OF TRADITIONAL INSTITUTIONS AND DEMOCRACY}

According to (Orji, \& Olali, 2010), traditional institutions refer to the native political provisions whereby leaders with confirmed track records are chosen and turban in line with the necessary requirements of their traditional customs and laws. The aims of the traditional institutions are to preserve the customs and traditions of the people in their localities and to make decisions on issues related to the political movement of the people in all the societies across the nation. However, traditional institutions played a significant role in managing conflicts rising between or among the public in their various communities using laws and customs of society.

Moreover, a study by Nweke (2012), pointed out that traditional institutions are the custodian of their people's norms, cultures, and practices. In the most African setting, just as it is available in Nigeria, appointing of people into various traditional institutions is hereditary or by election or selection by the relevant traditional rulers or kingmakers. This is in line with the beliefs of dependency theory, which believes that traditional rulers are supposed to have the autonomous power in the society, not to be a man by the politicians, this would help them perform their power in sustaining democracy in their respective jurisdictions. The mode of selection of traditional institutions differs from society to society. For instance, in Africa society in general and precisely Nigerian context it differs from one ethnic group to another ethnic group and communities to communities.

Traditional institutions are symbols of indigenous peoples' rights, privileges, laws, customs, and traditions which include but not limited to paramount rulers and their councils. The traditional institutions in the Nigerian context are inclusive of the chiefs-in-council, elders-incouncil, title holders who may be appointed based on their contributions to the growth and development of their communities with or little no executive, legislative or judicial powers (Orji \& Olali, 2010).

The above views are in line with the servant leadership theory, which postulated that leaders are supposed to serve the people first, then later people will serve them. The theory centered on the rulers that are above selfishness to help their followers. This dwelled on the leadership qualities such as honesty, respectfulness, humility, kindness, commitment, and patience, (Stone; Russell \& Patterson, 2004; as cited in Wooi \& Ismail, 2017).

\section{CONCEPT OF DEMOCRACY}

Democracy has been defined by several scholars based on their understanding and perceptions. A study by (Dunne, 2018) sees democracy as:

$$
\begin{aligned}
& \text { rule by the people', derived from the } \\
& \text { Greek 'demos', for 'common people', and } \\
& \text { 'kratos', for 'rule' or 'strength'. } \\
& \text { Democracy, in other words, is a form of } \\
& \text { government in which political control is } \\
& \text { exercised by all the people, either directly } \\
& \text { or through elected representatives. }
\end{aligned}
$$

In the early and original creation of democracy, it was used by the Greek City-state citizens as both political and Sociological senses i.e. (a way of life and form of government respectively); as a way of life which places values on individuals rights, equality of citizens, rank and appreciation of all persons and as a form of administrative preparation in which the inhabitants have the powers of choosing their leaders and exercise state powers either through direct or indirect means to control their affairs (Ahmed \& Shehu, 2014; Banjoko, 2004).

In a similar view Idiomond (2004), explained that democracy consists of four basic elements these includes:

$>$ A political system for choosing and replacing the government through free and fair elections.

$>$ The active participation of the people, as citizens, in politics and civic life.

$>$ Protection of the human rights of all citizens.

$>$ A rule of law, in which the laws and procedures apply equally to all citizens.

For instance, Ireland is a parliamentary, representative democratic republic. Scrap the 'directly' bit from the definition above: representative democracy is a form of government in which power is held by the people and exercised indirectly through elected representatives who make decisions and who are then held accountable for their activity within government (Dunne, 2018).

To justify the argument a study by Logan (2009), pointed out that it becomes important to account for the role of traditional leadership and institutions as part of, or together with, democratization processes. This is so not because these ruling classes are in some way integrally decent and democratic, but because, for better or worse, they are there, and they are clearly important exercises of "public 
authority" on the ground in most of the African societies. As a result, in the last decade, the discussion has increasingly shifted to a more pragmatic focus on understanding why these institutions continue, how they have changed and are ongoing to adjust to their changing political surroundings, and how various governments are coming to terms with them (Lund, 2006).

Similarly, a study by Osifo (2017), is of the same opinion with Lund (2006), that it is significant to outline the roles of traditional institutions to justify the argument on the role of traditional institutions on democratic movements in Nigeria. However, this study came up with seven roles of the traditional institution these includes but not limited to Maintaining peace and order, General advice, Custom and culture, Settlement of land disputes, Religious Authorizations, Social Authority, Recognition of outstanding members of the society.

\section{Findings}

The study found that traditional leaders play an important role in the democratic settings which include; maintaining of peace, advising the politicians, Help in Sustaining customs and culture, settling disputes among people, religious authorizations social power or authorities and recognition of outstanding members of the society among others.

\section{MAINTAINING PEACE}

The study found that sustainable peace and order in the society is one of the most important functions of the traditional rulers in every society, and the key for stable democracy, so, therefore, it is the responsibility of every citizen to play a role in maintaining peace, though this is one of the major duties of the traditional rulers in every society. More so, it is unveiled that to accomplish a stable democracy tradition must ensure peace and order in society. This is in line with the assumption of servant leadership theory, which suggested that leaders are supposed to serve the people first before people can serve them, this would help in sustaining democracy in the nation. Because leaders are supposed to show a good exemplary life for their followers to copy. The study further found that peace and order are essential for any economic activity to take place in any given society. Thus, the government depends on the traditional rulers in maintaining peace and order in their various domain. This is because the leaders know all members of the society, and in most cases, they have a direct connection with all the community elders, this would help in sustaining peace and order by disclosing any bad elements among the individuals in the society. From the above explanation, it is understood that leaders play a vital role in sustaining democracy. In line with this dependency theory believes that leaders help in maintaining steady democracy, and it further maintained that the problem of political instability is because of negating the power vested on the traditional rulers and assigning much power to political leaders over the traditional rulers. To accomplished stable democracy, traditional rulers should have autonomous power to discharge their responsibilities. This statement is in line with dependency theory leadership theory, which centered on leadership autonomy.

For instance, people leaving in an environment know themselves very well, if there is any new face or faces in the community or the society the people in that society must know, as such it will be very easy for them to fish out any criminal in their midst and hand over the perpetrator to the designated institution for further necessary action that is for trial and penalty by using communal policing or Villante group. This would help in sustaining peace and upholding steady democracy in the various communities and the society at large.

\section{ADVISING THE POLITICIANS}

Traditional institutions plays a significant role in sustaining stable democracy in any given society, this is because they advise the elected leaders in different areas, these include; economic policy, security, equal distribution of social services, nomination of aspirants for elections or appointment to serve the country customs and culture, demand for good governance and general wellbeing of the people among others. It is believing that "leaders' advice is the word of wisdom". This advice helps in maintaining firm democracy in the nation.

\section{Help in Sustaining Customs and CUlture}

Customs and culture here mean a total way of life of persons of a society that differentiate them with one another. Considering the heterogeneity nature of the nation, it is observed that Nigeria comprises people of different background, culture, and ethnic groups. It encompasses over 371 ethnic groups, each ethnic group has its own culture and custom that separate them from other communities (Sowunmi, 2017).

This gives the nation the peculiar nature of ethnic rivalries. Suspicious is widespread between these ethnic groups that formed the nation. However, traditional institution assists in uniting the people through campaigning strength in diversity than separation. All the ethnic groups are under the leadership of the traditional rulers of their various communities. Traditional rulers have the power to control their behaviors toward stable democracy in society, as such, they deserve leadership autonomy that can enable them to discharge their roles in society. This would help in accomplishing stable democracy and good governance (Sami et al., 2018; Sowunmi, 2017).

\section{Settling Disputes Among People}

Political and religious crises have become a phenomenon every in the nation. To curtail these problems in society, the roles of the traditional institution became apparent. To explain this a study by Lund, 2006 and Osifo (2017), stated that traditional rulers play a significant role in settling a dispute among people in their respective domain, they make sure they settle the land-related dispute, community disputes, religion crises before they worsen into exposed aggressions where people killed one another. It is understood that land dispute is the major root of conflict in most of the rural communities where land has become the major primary means of making wealth and earning a living through subsistence and commercial agriculture. In this case, the government depends on the traditional rulers in ensuring peace among the people. By making sure that they settle or overcomes all the hostilities between individuals in each locality and do not escalate into ethnic conflict. This would help in upholding steady democracy in society.

\section{RELIGIOUS AUTHORIZATIONS}

In the olden day's traditional institutions use religion authorities to settle and deal with disputes among married couples in the society, it also uses religious sanctions to resolve issues related to land disputes among the people in their respective communities, and issues like stealing, and disputes between neighbor in their societies. Although adherent to the local traditional religion is few nowadays. However, the use of traditional gods and swearing oaths is another way of stopping social recklessness and misconducts in the communities. It is also observed that the fear of what traditional gods could do kept several politicians in check from embezzling public account in the past. Currently, this has put fear in the mind of the politicians and has warned, yet it is a way to keep public servants focused on services to humanity than on personal interest. This would help in attaining peace and order among the citizen's firm democracy in the nation.

\section{SOCIAL AUTHORITY OR POWER}

Before, traditional rulers play an important role in the society, this is because of the leadership power vested on them, and the power they 
have over the general populous of their respective province, using social authorities. The used of social authorities help in accomplishing firm democracy in society. The study found that traditional rulers influence the selection of who should stand for elective positions to represent people at the local, state, and national levels. In this case, traditional rulers choose those that have the zeal to protect the right and interest of the people in their area of administration. This would help in sustaining firm democracy in the nation.

\section{ReCognition of OUtStanding Members of the SocietY}

In discussing the role of the traditional institution in sustaining firm democracy in the Nigerian context, the recognition of outstanding members of the society is important. Awarding of chieftaincy title to recognized outstanding members of the society help to keep the moral compass of the society up. People get chieftaincy titles when they distinguish themselves in their field of enterprises and serves as a role model for creating a better society. And those that have the vision and mission of uplifting the society to a better position, by rendering selfless services to the various communities, by extension to the nation at large.

\section{ROLES OF TRADITIONAL INSTITUTIONS IN ACCOMPLISHING SUSTAINABLE DEMOCRACY IN NIGERIA}

Numerous scholars such as (Adesoji, 2010; Emordi and Osiki, 2008; Onoja 2007; Orji, and Olali, 2010), are of the opinion that traditional institutions in modern Nigeria are confronted with several matters such as struggle for headship among traditional leaders in the Assembly of Traditional Leaders, participation in biased politics for individual gains and giving support for the reigning governments whether military or civilian. Knowingly, the traditional rulers in the Nigerian context have also been suspected of continuous involvement in traditional centenary and ceremonial despite contemporary inspirations. Besides, traditional institutions in Nigeria are caring of giving traditional rulers titles to rich and prosperous people in the society who have not made any important contribution to the development and growth of the society for their individual exaggeration and physical gains. As maintained above, all these are criticisms of the traditional institutions in contemporary Nigeria are insightful of the over-all political corruption in the country and not exceptional to traditional leadership (Ofuafor, 2010).

In a similar version, a study by Matunhu (2011), lamented that political, cultural, and economic dependency of the African land upon Europe and America. Likewise in another opinion, a study by Rodney (1972), disclosed that African political freedom from the imperialism has not altered the dependence but it somewhat developed it. It argued that the political independence of Africa from colonialism did not alter the dependency arrangement rather it deepened it. He further, explained that African nationalism has not in any way discouraged the colonialist from governing Africa. The study found that lack of political will and capacity from the side of the government and lack of local contribution in the planning and equal distribution of national resources and welfare service among the general populous are the main factors contributing to the poor state of democratic dividends.

In line with the above argument Akani (2010), unveiled that African traditional institutions have also contributed to destroying the African traditional institutions. This is because of the attitude of some traditional institutions that have been politicizing by the corrupt politicians, for personal interest, so also some of the traditional rulers have polluted mind that has contributed to negating the power of the traditional rulers in maintaining stable democracy in the nation. In line with this dependency theory suggested that leaders are supposed to be truthful, dedicated, honest and above all accountable, this would help in sustaining stable democracy and good governance.

\section{Recommendation}

The paper has recommended that to accomplished steady democracy traditional rulers should be given full autonomy and well connected into Nigeria democratic procedure this would encourage them to contribute in no small measure to the democratic developmental process. It is known that Nigeria is branded with a series of conflict, religion and ethnic violence. In this case if the traditional rulers are given the autonomous power and can exercise the power in conflict resolution, all problems of national question which originates from religion, ethic and cultural interest will be minimized using Nigerian judicial process as all the traditional leaders whose areas are affected will meet one another as well as those involve in the conflict. This is because all the Traditional institutions are joint above tribalism, religion, and ethnic differences, they see themselves as a traditional force for preserving people cultures and traditions. This would help in bringing and improving peace that would lead to a stable and sustainable democracy in the country.

Political indifference has become a menace to Nigeria democracy as many peoples are not willing and ready to take part in the political process. The study further recommended that democratization of the States along traditional institution can help to enhance economic growth and democratic dividends. This includes the ability of traditional authorities' capacity and influence to mobilize people of their various local communities to get involved in politics, thus, empowering them to play a part in influencing strategy. The study than noted that Traditional institution if unified very well will not only meet with contemporary democratic standards but would have the potential to balance the strategies of modern democracy by filling the gaps in the applicability of modern democratic strategies. They can also help in bringing in those relegated individuals of society.

More so, the study recommended that Traditional institutions in Nigeria if well connected are a feasible tool for enhancing peace and sustainable democracy by involving them into the system. The study further suggested that traditional laws and ethics are the major obligations for Nigeria social development. Traditional rulers especially those at the local level, are nearer to the people and they take part in media where local interests are discussed and expressed. Therefore, they can establish a valued resource in notifying the state about the interests of communities as well as in mobilizing rural inhabitants for active engagement, not only in developmental activities and the allocation and distribution of resources and public services but also in the national political progression.

\section{Conclusion}

The paper concluded that, before the advent of the colonial administration, traditional institutions played a significant role in the democratic set up, to regain the proper role of the traditional institutions in the national development, there is pressing need for the government or Nigerian state to reinforce the traditional institutions of governance by rapidly specifying their roles and their mode of operations in the Nigerian Constitution to support their activities, in this regard some lawful outline and backing should be put in place. With this, the traditional institutions of governance would have been wholly disconnected from the bibs of political mixing with the politicians so that the traditional organizations would recover their respects and values in a bid to exercising the kind of power they had before and during the colonial era in democratic movements. The paper accomplishes by investigating the possible advantage of reintegrating the traditional institutions into Nigeria system of governance such as the provision of the basic moral and political awareness for the citizen through massive political mobilization. The study noted and concludes that traditional institution if well unified can help in minimizing issues such as ethnic relegation and ethnic crises as well as religious disputes that arise as a result of political interest through societal laws and customs process that assured the spirit of the relationship after conflict. If all traditional institution is not the grief of the issue of relevance rather than the constitutional 
role and an effective re-integration will help to provide sustainable peace, development, and democracy.

\section{References:}

Adesoji, A. O. (2010). Traditional Ruler Ship and Modern Governance in the 20th Century. In: Babawale, T., A. Alao and A. Adesoji (Eds.), the Chieftaincy Institution in Nigeria.Concept Publishers for Centre for Black and African Arts and Civilization, Lagos, Nigeria.

Ahmed, M., \& Shehu, M. I. (2014). Democracy and Its Adoption in Nigeria : Western Liberal or Indigenous Option, 5, 63-68.

Akani, C. (2010). The Enlightenment and the Rise of Colonialism in Africa. Port Harcourt: Paragraphs.

Ali A, M., Zakuan A A, U., \& Ahmad M. Z, (2018). Northern Nigerian Women Participation in Trade Union Movement: Impediments and Solutions. Journal of Humanities and Cultures Studies R\&D, 4. Retrieved from https://www.jsrd-humanities.com

Banjoko, O. O. (2004). Universal Democracy (Holocracy): A Rule by All Parties. Ibadan: Spectrum Books Ltd. Constitution of the Federal Republic of Nigeria, 1999.

Braun and Clarke. (2013). Successful Qualitative Research a Practical Guide for Beginners.

Creswell, J. W. (2013). Research Design: Qualitative, Quantitative and Mixed Method Approaches. SAGE Publications.

Creswell J.W. (2009). Research Design: Qualitative, Quantitative, and Mixed Methods Approaches. London SAGE Publication, Incorporated.

Emordi, E.C. and O.M. Osiki. (2008). The traditional rule in Nigeria: The crisis of relevance in contemporary politics. Ife J. History., 4, 67-92.

Idiomond I. (2004). What is Democracy? Lecture at Hilla University for Humanistic Studies.

Justin F. (2018). Largest Ethnic Groups In Nigeria. World Atlas.

Kenneth K. and Toyin F. (2018). Introduction: Exploitation, Colonialism, and Postcolonial Misrule in Africa.

Diamond L. (1988). Class, Ethnicity, and Democracy in Nigeria: The Failure of the First Republic.

Linnea D. (2018). Rule of the People, anyone? on Democracy and the System being broken.

Logan, C. (2009). Selected chiefs, elected councilors and hybrid democrats : popular perspectives on the coexistence of democracy and traditional authority. The Journal of Modern African African Studies, 47(1), 101128. https://doi.org/10.1017/S0022278X08003674

Lund, C. (2006). Twilight institutions: public authority and local politics in Africa', Development and Change., 37(4), 685-705.

Matunhu, J. (2011). A Critique of Modernization and Dependency Theories in Africa: Critical Assessment. Retrieved January 2, 2019, from http://www.academicjournals.org./AJHC. Africa Journal of History and Culture, 3(5), 65-72.

Nachmias, D. \& Nachmias, C. (1981). Research Methods in Social Sciences (2nd ed.). New York: St Martins Press.

Nweke, K. (2012). The Role of Traditional Institutions of Governance in Managing Social Conflicts in Nigeria's Oil -Rich Niger Delta Communities: Imperatives of Peace-Building Process in the PostAmnesty Era EEE. British Journal of Arts and Social Sciences, 5(2), 202-219.

Ofuafor, M. O. (2010). Rethinking the Chieftaincy 'Imperative' in Engendering Grassroots Development in Nigeria. In: Babawale, T., A. Alao and A. Adesoji (Eds.), the Chieftaincy Institution in Nigeria. Concept Publishers for Centre for Black and African Arts and Civilization, L.

Onah, F. O. \& Nyewusira, V. (2006). Foreign Debt Conundrum and Nigeria's Socio-Economic Development. ,. Journal of International Politics and Development Studies, 2(1), 13-17.

Onoja, A. (2007). Redefining Tradition: The Chieftaincy Institution in Nigeria. Ife Journal of History, 4(2), 227-243.

Orji, K. E. \& Olali, S. T. (2010). Traditional Institutions and Their Dwindling Roles in Contemporary Nigeria: The Rivers State Example. In T. Babawale, A. Alma \& B. Adesoji (eds.) Chieftaincy Institution in Nigeria. Lagos: Concept Publication Ltd.

Paden, J. N. (1986). Values and leadership in Nigeria: Ahmadu Bello Sardauna of Sokoto. Zaria: Huda-Huda Publishing Press.

Rodney, W. (1972). How Europe Underdeveloped Africa. Abuja: Panaf Press.

Sami, A., Jusoh, A., Mahfar, M., Qureshi, M. I., \& Khan, M. M. (2016). Role of Ethical Culture in Creating Public Value. International Review of Management and Marketing, 6(4S).

Sami, A., Jusoh, A., Md. Nor,K., Irfan,I., \& Qureshi, M. I. (2018). Systematic Review of Public Value. Journal of Public Value and Administration
Insights, 1(1), 1-6.

Silas O. (2018). Ethnic groups in Nigeria.

Stone, A. G., \& Patterson, K. (2005). The history of leadership focus.Servant leadership research roundtable proceedings.School of Leadership Studies, Regent University, Virginia Beach, US.

Stone, A. G., Russell, R. F., \& Patterson, K. (2004). Transformational versus servant leadership: a difference in leader focus. Leadership \&Organization Development, 25(4), 349-361.

UNDESA. (2018). United Nations Department of Economic and Social Affairs: Population Division; Countrymeters.

Osifo. V. (2017). 7 Roles of Traditional Rulers in Achieving Stable Democracy in Nigeria. Information Guide in Nigeria.

Washington, R. R. (2007). Empirical relationships between theories of a servant, transformational, and transactional leadership. In Academy Of Management Proceedings, 2007 (1), 1-6, Academy of Management., $1(1), 1-6$.

White, L.G. \& Clark, R. P. (1990). Political Analysis: Technique and Practice. California: Brooks/Cole Publishing Company.

Wooi, C. T., \& Ismail, I. A. (2017). Lessons from the Major Leadership Theories in Comparison to the Competency Theory for Leadership Practice. Journal of Business and Social Review in Emerging Economies, 3(2), 147-156.

Isaac. Y. O, (2018). Role of Traditional Institution in Nigeria Democratic Space: Contending Perspectives, Issues, and Potentials.

Zaleha O. (2018). Important things about Qualitative Research.

Sowunmi, Z, K. (2017). A full list of all 371 tribes in Nigeria, states where they originate. Vanguard. 